\title{
Preparation of a copper-based fluorescent probe for nitric oxide and its use in mammalian cultured cells
}

\author{
Mi Hee Lim \\ Department of Chemistry, Massachusetts Institute of Technology, Cambridge, Massachusetts 02139, USA. Present address: Division of Chemistry and Chemical \\ Engineering, California Institute of Technology, Pasadena, California 91125, USA. Correspondence should be addressed to M.H.L. (miheelim@alum.mit.edu). \\ Published online 8 March 2007; doi:10.1038/nprot.2007.43 \\ A procedure for the preparation of a copper(II) complex (CuFL) as a fluorescent nitric oxide (NO) detector is described. The \\ fluorescein-based ligand $\mathrm{FL}$ can be synthesized in seven reaction steps (overall yield $\sim 20 \%$ ), typically requiring a total time of \\ 9 days. The CuFL probe allows for the detection of NO produced in mammalian cultured cells. The detailed protocol for the use of \\ CuFL for imaging NO in human neuroblastoma SK-N-SH cells takes a total time of $\sim 26 \mathrm{~h}$. This includes plating cells on six-well \\ tissue culture plates or imaging dishes, treatment with CuFL, stimulation of NO synthases and imaging by fluorescence microscopy.
}

\section{INTRODUCTION}

The free radical NO as a signaling messenger regulates a variety of biological activities ${ }^{1-5}$. To ascertain the roles of $\mathrm{NO}$ in biological contexts, a tool capable of revealing its location and movement upon production is needed. Small-molecule-based sensors in conjunction with fluorescence microscopy have proven useful in visualizing biological analytes such as $\mathrm{Ca}(\mathrm{II}), \mathrm{Zn}(\mathrm{II})$ and reactive oxygen species (i.e., hydrogen peroxide, superoxide, hydroxyl radical and singlet oxygen) with spatial and temporal resolution $^{6-9}$. Fluorescent sensors for imaging NO and its derivatives have also been developed and applied to biological samples ${ }^{10-14}$. Organic molecule-based indicators have commonly been used for imaging NO, but they exhibit a fluorescence response to products of $\mathrm{NO}$ oxidation, such as $\mathrm{N}_{2} \mathrm{O}_{3}$, and thus detect NO only indirectly ${ }^{10,11,14}$. To monitor NO directly, we have explored transition-metal-based sensors that can display an increase in fluorescence through interaction of $\mathrm{NO}$ with the metal center ${ }^{11,13}$.

Recently, we developed a transition-metal complex CuFL (Fig. 1, FL = 2-\{2-chloro-6-hydroxy-5-[(2-methyl-quinolin-8-ylamino)-methyl]-3-oxo-3H-xanthen-9-yl\}-benzoic acid), which offers direct sensing of $\mathrm{NO}^{12,13,15}$. The CuFL probe is prepared in situ by mixing $\mathrm{FL}$ with copper(II) chloride $\left(\mathrm{CuCl}_{2}\right)$ in the ratio of $1: 1$. The supporting ligand $\mathrm{FL}$ for $\mathrm{Cu}(\mathrm{II})$ is a fluorescein derivative
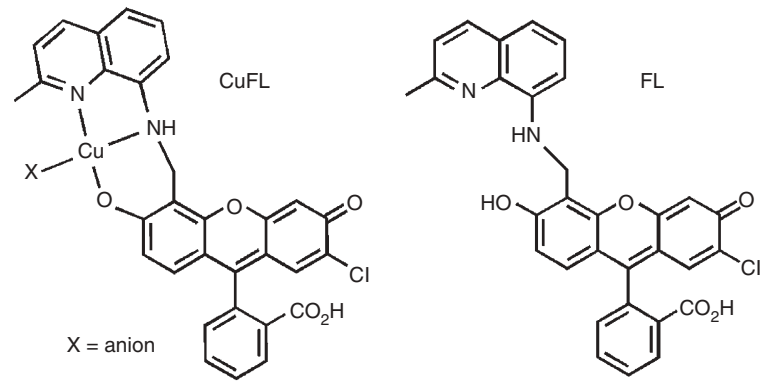

Figure 1 | CuFL and FL.

and can be synthesized from phthalic anhydride, 4-chlororesorcinol, 2-methylresorcinol and 8-aminoquinaldine as described in Figure 2 (see refs. 12,16,17). Studies of CuFL in aqueous buffered solution ( $\mathrm{pH} 7.0)$ suggest that it immediately exhibits a NO-induced 11-fold increase in fluorescence ${ }^{12,15}$. Furthermore, the molecule CuFL shows fluorescence turn-on upon NO production in cells ${ }^{12}$. The protocol outlined below summarizes the preparation and usage of CuFL to image NO in mammalian cultured cells such as human neuroblastoma SK-N-SH cells.

\section{MATERIALS}

\section{REAGENTS}

- Aluminum chloride ( $\mathrm{AlCl}_{3}$, anhydrous; Aldrich, 449598) ! CAUTION Handle with care (corrosive).

-Aluminum foil

- Aluminum oxide (Aldrich, 199974)

-8-Aminoquinaldine (purity $>98 \%$; TCI, A0416)

- Magnesium sulfate ( $\mathrm{MgSO}_{4}$, anhydrous; EMD, MX0075-1)

$\cdot 1,1^{\prime}$-Azobis(cyclohexanecarbonitrile) (VAZO 88, purity 98\%; Aldrich, 380210)

- Benzoic anhydride (purity 90\%; Aldrich, 385980)

-4-Chlororesorcinol (purity 98\%; Aldrich, C70606)

- Chlorobenzene $\left(\mathrm{C}_{6} \mathrm{H}_{5} \mathrm{Cl}\right.$, anhydrous; Aldrich, 284513) ! CAUTION Handle

with care (carcinogenic, flammable).

- Chloroform $\left(\mathrm{CHCl}_{3}\right.$; Aldrich, 372978 (anhydrous), EMD, CX1059-1

(99.8\%)) ! CAUTION Handle with care (carcinogenic).

- Celite 545 (EM Science, CX0574-1)! CAUTION Handle with care

(carcinogenic).
- Copper(II) chloride ( $\mathrm{CuCl}_{2}$, anhydrous; Aldrich, 451665)

$\cdot$ 1,3-Dibromo-5,5-dimethylhydantoin (purity 98\%, Aldrich,

157902)

- Deionized water $\left(\mathrm{H}_{2} \mathrm{O}\right.$; Millipore $)$

- Dichloromethane $\left(\mathrm{CH}_{2} \mathrm{Cl}_{2}\right.$; EMD, DX0835-6, ACS reagent grade)

! CAUTION Handle with care (carcinogenic).

- Dimethyl sulfoxide (DMSO, anhydrous; Aldrich, 276855)

- Dulbecco's modified Eagle's media (cell culture tested; Gibco-BRL, 11965-092)

-17ß-Estradiol (purity $\geq 98 \%$; Sigma, E2758) ! CAUTION Handle with care (experimental carcinogen in animals).

-Ethanol (EtOH; anhydrous; Aldrich, 459836) ! CAUTION Handle with care (flammable).

- Ethyl acetate (EtOAc; EMD, EX02451 (reagent grade); Aldrich, 270989 (anhydrous for Step 47)) ! CAUTION Handle with care (flammable).

- Glacial acetic acid (HOAc, J.T. Baker, 9507-00) ! CAUTION Handle with care (corrosive). 
- Heat-inactivated fetal bovine serum (FBS; HyClone, SH30071.03)

-Hexanes (EMD, HX0299-5, reagent grade)

! CAUTION Handle with care (flammable).

-Human neuroblastoma SK-N-SH cells (American

Type Culture Collection, HTB-11)

-Hydrochloric acid (HCl; J.T. Baker, 9535-00)

! CAUTION Handle with care (corrosive).

- Methanol $\left(\mathrm{CH}_{3} \mathrm{OH}\right.$; Aldrich, 322415 (anhydrous

form for Step 48); EMD, MX0485-7 (reagent

grade)) ! CAUTION Handle with care

(flammable).

-2-Methylresorcinol (purity 98\%; Aldrich, 302589)

- Molecular sieves, 3- $\AA$ (EM Science, MX1583D-1)

- Nitrobenzene $\left(\mathrm{C}_{6} \mathrm{H}_{5} \mathrm{NO}_{2}\right.$, ACS reagent grade;

Aldrich, 252379) ! CAUTION Handle with care

(carcinogenic).

- Nonessential amino acid for minimal essential media (cell culture tested; Sigma, M7145)

- Penicillin and streptomycin (cell culture tested; Gibco, 15140-122)

- Phosphate-buffered saline (1× PBS; Gibco, 10010-023)

- Phthalic anhydride (ACS reagent grade; Aldrich, 320064) ! CAUTION Handle with care (corrosive).

- Preparative thin-layer chromatography (TLC) plates (Whatman F254 silica gel-60 plate of $1 \mathrm{~mm}$ thickness)

- Pyridine (anhydrous; Aldrich, 270970) ! CAUTION Handle with care

(flammable).

- Sand (EMD, SX0070-1)

- Silica gel 60 (EMD, 93853)

- Sodium bicarbonate $\left(\mathrm{NaHCO}_{3}\right.$; Mallinckrodt Chemicals, 7412-12)

- Sodium borohydride $\left(\mathrm{NaBH}_{4}\right.$, purity $99.99 \%$; Aldrich, 480886)

- Sodium pyruvate (cell culture tested; Sigma, S8636)

- TLC plates, silica gel

- Toluene (anhydrous; Aldrich, 244511) ! CAUTION Handle with care (flammable, experimental teratogen).

-Zinc(II) chloride ( $\mathrm{ZnCl}_{2}$, anhydrous; Aldrich, 429430) ! CAUTION Handle with care (corrosive).

\section{EQUIPMENT}

- Beakers

- Condensers

- Eppendorf tubes

- Erlenmeyer flasks, filter flasks

- Filtering funnels, filter papers

- Glass frits

- Graduated cylinders

- Heating mantle

- Imaging dishes with a glass coverslip on the bottom $(3.5 \mathrm{~cm}$, sterile; MatTek Corporation)

- Incubator $\left(37^{\circ} \mathrm{C}\right.$, a humidified atmosphere of $\left.5-10 \% \mathrm{CO}_{2}(\mathrm{v} / \mathrm{v})\right)$

- Microscope (Nikon Eclipse TS 100 microscope: RT Diagnostic camera, Chiu Mercury $100 \mathrm{~W}$ lamp; FITC-HYQ filter cube

(excitation 460-500 nm, band pass 510-560 nm), Spot Advanced software. Zeiss Axiovert 200M inverted epifluorescence microscope: Hamamatsu camera, X-Cite 120 fluorescence illumination system (EXFO), differential interference contrast (DIC775DF50 emission), YFP filter (495DF10 excitation, 515DRLP dichroic, 530DF30 emission), Volocity software (Improvision)
- Media filtration an
polystyrene bottle)

- Mortar and pestle

- Pipettes

- Pyrex chromatographic columns $(6.4 \mathrm{~cm}$ i.d. $\times 63.5 \mathrm{~cm}$ long with a $500-\mathrm{ml}$ reservoir)

- Round-bottomed flasks

- Separatory funnels

- Spatulas

- Teflon-coated magnetic stir bars

- Thermometers

- TLC developing chamber

- Tubes (Corning centrifuge tube)

- Six-well tissue culture plates (sterile)

-UV hand-held lamp

REAGENT SETUP

Solvents Dry pyridine and EtOAc over 3- $\AA$ molecular sieves

$\left(\sim 40 \mathrm{mg} \mathrm{ml}^{-1}\right)$ overnight before use in reactions, or use straight from a newly purchased bottle of anhydrous forms (pyridine, Aldrich, 270970; EtOAc, Aldrich, 270989). Filter $\mathrm{C}_{6} \mathrm{H}_{5} \mathrm{NO}_{2}$ and $\mathrm{C}_{6} \mathrm{H}_{5} \mathrm{Cl}$ through aluminum oxide immediately before use in the reactions. Note that any water contamination can lower the yields of the desired reactions.

Medium Dulbecco's modified Eagle's media, 10\% (v/v) heat-inactivated fetal bovine serum, $1 \mathrm{mM}$ sodium pyruvate, $100 \mathrm{U} \mathrm{ml}^{-1}$ penicillin, $100 \mu \mathrm{g} \mathrm{ml}^{-1}$ streptomycin and $0.1 \mathrm{mM}$ nonessential amino-acid solution for minimal essential media.

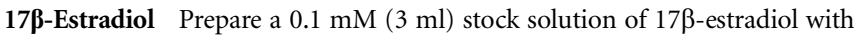
DMSO.

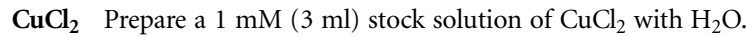

EQUIPMENT SETUP

Glassware All glassware has to be completely dry before use in the synthesis of FL and its precursor (see Solvents in REAGENT SETUP). Store all flasks in the $140{ }^{\circ} \mathrm{C}$ oven for at least $4 \mathrm{~h}$ before use.

Microscope Optimize the parameters such as the excitation exposure time and the light intensity to obtain an image (sufficient signal to noise) without photobleaching. In the Nikon Eclipse TS microscope system, cells are plated on six-well tissue culture plates for imaging. Imaging dishes with a glass coverslip on the bottom are used for plating cells for the Zeiss Axiovert 200M inverted epifluorescence microscope system.

\section{PROCEDURE}

\section{Synthesis of 2'-carboxy-5-chloro-2,4-dihydroxybenzophenone (1) $\bigcirc$ TIMING $\sim 1$ day}

1) Weigh $9.0 \mathrm{~g}$ of phthalic anhydride $(61 \mathrm{mmol})$ and $8.5 \mathrm{~g}$ of 4-chlororesorcinol (59 mmol) and transfer them to a $300-\mathrm{ml}$ round-bottomed flask containing a Teflon-coated magnetic stir bar ${ }^{16}$.

2| Transfer $150 \mathrm{ml}$ of $\mathrm{C}_{6} \mathrm{H}_{5} \mathrm{NO}_{2}$ to the flask and cool it in an ice bath.

3| Slowly add $18 \mathrm{~g}$ of $\mathrm{AlCl}_{3}(0.14 \mathrm{~mol})$ in three equal portions over $1 \mathrm{~h}$. Stir the reaction mixture in the same bath (Step 2) overnight while warming to room temperature $\left(\sim 22{ }^{\circ} \mathrm{C}\right)$.

! CAUTION Handle with care, as the addition of $\mathrm{AlCl}_{3}$ may cause explosions.

$\triangle$ CRITICAL STEP The aliquots of $\mathrm{AlCl}_{3}$ must be weighed out immediately before use with a dry spatula ( $\mathrm{AlCl}_{3}$ is highly hydroscopic). 
PROTOCOL

4| Dilute the reaction mixture with $700 \mathrm{~mL}$ of $0.1 \mathrm{M} \mathrm{HCl}(\mathrm{aq})$ and $100 \mathrm{ml}$ of hexanes and collect the black-brown precipitate that forms by filtering through a glass frit into a filter flask.

5| Wash the solid with hexanes and $\mathrm{H}_{2} \mathrm{O}$ and dry it for $1 \mathrm{~h}$ under vacuum.

6| Dissolve the crude product in a minimum volume of boiling $\mathrm{CH}_{3} \mathrm{OH}(\sim 10 \mathrm{ml})$ and then add boiling $\mathrm{H}_{2} \mathrm{O}(\sim 60 \mathrm{ml})$ to recrystallize.

7| Allow the solution to cool to room temperature.

PAUSE POINT Store the solution in a refrigerator $\left(4^{\circ} \mathrm{C}\right)$ overnight.

8| Collect the brown crystalline product by using a glass frit and a filter flask and dry it under vacuum. Please note that 1 can be recrystallized more than once to afford the pure product.

- PAUSE POINT Compound 1 can be stored at $4{ }^{\circ} \mathrm{C}$ for at least 3 years.

\section{Synthesis of 2'-chloro-5'-methylfluorescein (2) $\bigcirc$ TIMING $\sim 4 \mathrm{~h}$}

9| Weigh out $5.0 \mathrm{~g}$ of $\mathbf{1}(17 \mathrm{mmol})$ and $2.1 \mathrm{~g}$ of 2-methylresorcinol (17 mmol) (see ref. 16).

10| Grind these compounds with a mortar and a pestle into a homogeneous mixture and transfer them into a $100 \mathrm{ml}$ round-bottomed flask.

11 Heat the reaction mixture to $150{ }^{\circ} \mathrm{C}$ by using a heating mantle to melt it into an off-white sticky material (could also be a brown liquid).

12| Add $2.3 \mathrm{~g}$ of $\mathrm{ZnCl}_{2}(0.11 \mathrm{~mol})$ gradually over $35 \mathrm{~min}$. Cover the whole surface of the reaction mixture with the portions of $\mathrm{ZnCl}_{2}$. The reaction turns deep red when $\mathrm{ZnCl}_{2}$ is added.

$\triangle$ CRITICAL STEP $\mathrm{ZnCl}_{2}$ should be a fine powder; the presence of aggregates (clumps) in the material would indicate water contamination, which should be avoided, see REAGENT SETUP.

13| Slowly increase the temperature to $250{ }^{\circ} \mathrm{C}$ over $30 \mathrm{~min}$. Mix the reaction mixture with a spatula, keep it at this temperature for $10 \mathrm{~min}$ and cool it to room temperature to give a solidified material.

14| Remove the brick red solid from the round-bottomed flask and pulverize the brick red solid with a mortar and a pestle. Note that it is helpful to freeze the reaction flask with liquid nitrogen to obtain the solid.

I CAUTION Be careful not to break the round-bottomed flask when trying to remove the solid.

15| Transfer the solid to a beaker containing $250 \mathrm{ml}$ of $3 \mathrm{M} \mathrm{HCl}$ (aq) and a Teflon-coated magnetic stir bar and boil for $30 \mathrm{~min}$ by using an oil bath.

16| Collect the red solid by filtering through a glass frit into a filter flask after cooling the solution to room temperature.

17| Dry the solid under vacuum. Note that the solid includes 2 and $4^{\prime}, 5^{\prime}$-dimethylfluorescein $(\sim 10 \%)$. Use this material for synthesis of $\mathbf{3}$ without further purification.

PAUSE POINT Compound 2 can be stored safely at $4{ }^{\circ} \mathrm{C}$ for at least 3 years.

\section{Synthesis of $7^{\prime}$-chloro-4'-methylfluorescein dibenzoate (3) $\bigcirc$ TIMING $\sim 3$ days to a week}

18| Weigh out $4.8 \mathrm{~g}$ of $2(14 \mathrm{mmol})$ and $13 \mathrm{~g}$ of benzoic anhydride (58 mmol)) (see ref. 17).

19| Transfer them into a $250 \mathrm{ml}$ round-bottomed flask and add $75 \mathrm{ml}$ of pyridine.

20| Reflux the solution under $\mathrm{N}_{2}$ atmosphere (flowing $\mathrm{N}_{2}(\mathrm{~g})$ ) for $2.5 \mathrm{~h}$ by using a condenser and an oil bath $\left(\sim 120^{\circ} \mathrm{C}\right)$. To produce a $\mathrm{N}_{2}$ atmosphere in the reaction apparatus, insert an inlet from a Schlenk line connected to a $\mathrm{N}_{2}(\mathrm{~g})$ tank and an outlet (connected to a bubbler) to the top of the condenser. Open the gas manifold to obtain a continuous (but controlled) flow of gas through the system (as monitored through the bubbler installed at the end of the line).

21 Cool the dark-brown solution to $90{ }^{\circ} \mathrm{C}$ and pour it into a beaker containing at least $300 \mathrm{ml}$ of water.

! CAUTION Handle the hot solution with care.

22| Stir the solution vigorously from which a brown sticky solid separates. 
23| Stop stirring the solution and wait for the solid to settle on the bottom of the beaker. Replace water. Repeat this step periodically over 2 days to obtain a light tan powder. Frequently change water during the first day. This procedure can be prolonged for an entire week to collect most of the light tan materials.

24| Collect the powder by filtering through a glass frit into a filter flask and dry it in air.

25 Partially dissolve the powder with a minimum volume of toluene $(\sim 3 \mathrm{ml})$ and add $\mathrm{EtOH}(\sim 50 \mathrm{ml})$ to prompt precipitation of an off-white solid.

26| Collect the off-white precipitate 3 by filtration through a glass frit and wash it with EtOH. Dry it under vacuum. Note that the solid includes 3 and $4^{\prime}, 5^{\prime}$-dimethylfluorescein dibenzoate $(\sim 10 \%)$. Use this material for synthesis of 4 without further purification.

PAUSE POINT Compound 3 from Step 26 can be stored safely at $4{ }^{\circ} \mathrm{C}$ without further purification for at least 3 years.

\section{Synthesis of 7'-chloro-4'-bromomethylfluorescein dibenzoate (4) TIMING $\sim 2$ days to over $\mathbf{4}$ days}

27| Weigh out $3.7 \mathrm{~g}$ of $3(5.5 \mathrm{mmol}), 0.17 \mathrm{~g}$ of VAZO $88(70 \mu \mathrm{mol})$ and $1.6 \mathrm{~g}$ of 1,3-dibromo-5,5-dimethylhydantoin $(5.5 \mathrm{mmol})$ ) (see ref. 17).

28| Transfer compounds into a round-bottomed flask (500 ml) containing $250 \mathrm{ml}$ of $\mathrm{C}_{6} \mathrm{H}_{5} \mathrm{Cl}$ and a Teflon-coated magnetic stir bar.

29| Stir the reaction mixture at room temperature and add $100 \mu \mathrm{l}$ of $\mathrm{HOAc}$. Heat the solution to $60{ }^{\circ} \mathrm{C}$ for $48 \mathrm{~h}$ under $\mathrm{N}_{2}$ atmosphere (see Step 20 for details on how to obtain a nitrogen atmosphere in the reaction vessel) and then cool it to room temperature. Note that the reaction may take 4-6 days or longer (addition of VAZO 88 every day may help the progress of the reaction) and should be monitored by ${ }^{1} \mathrm{H}$ NMR spectroscopy to check for the disappearance of the $\mathrm{CH}_{3}$ resonance ( 2.3 p.p.m.) of 3 and for the appearance of the $\mathrm{CH}_{2} \mathrm{Br}$ resonance ( 4.8 p.p.m.) of 4 .

$\triangle$ CRITICAL STEP Heating the solution above $60{ }^{\circ} \mathrm{C}$ will cause the reaction to fail.

30| Extract the resulting orange solution with warm water $(3 \times 250 \mathrm{ml})$ by using a separatory funnel.

31 Collect the organic layer in an Erlenmeyer flask and dry it adding excess anhydrous $\mathrm{MgSO}_{4}\left(\sim 35 \mathrm{mg} \mathrm{ml}^{-1}\right.$, shaking the solution for $\sim 3 \mathrm{~min}$ ).

32 Filter the solution under gravity through a filter paper on a glass funnel to remove $\mathrm{MgSO}_{4}$ and collect the filtrate in a round-bottomed flask.

33 Remove the solvent from the filtrate by using a rotary evaporator ( $\sim 50$ to $\sim 60^{\circ} \mathrm{C}$ ) to give an orange solid.

34| Partially dissolve the solid in a minimal volume of toluene $(\sim 3 \mathrm{ml})$.

35 Add $\sim 50 \mathrm{ml}$ of EtOH to cause the appearance of a peach-colored powder. Collect the solid by filtration through a glass frit and dry it under vacuum. Please note that the solid also contains 4 and bis-(bromomethyl) derivative ( $\sim 10 \%)$. Use this material for synthesis of $\mathbf{5}$ without further purification.

PAUSE POINT Compound 4 from Step 35 can be stored safely at $4{ }^{\circ} \mathrm{C}$ without further purification for at least 3 years.

Synthesis of $7^{\prime}$-chloro-4'-fluoresceincarboxaldehyde (5) $\bigcirc$ TIMING $\sim 10 \mathrm{~h}$

36 Weigh out $4.0 \mathrm{~g}$ of $4(5.3 \mathrm{mmol})$ and $4.5 \mathrm{~g}$ of $\mathrm{NaHCO}_{3}(53 \mathrm{mmol})$ (see ref. 17).

37| Combine them in a round-bottomed flask $(200 \mathrm{ml})$ and add $75 \mathrm{ml}$ of DMSO.

38 Heat the reaction mixture to $150{ }^{\circ} \mathrm{C}$ for $3 \mathrm{~h}$ by using an oil bath. The solution turns from light orange to deep red over the course of $1 \mathrm{~h}$.

39| Cool the solution to $\sim 70{ }^{\circ} \mathrm{C}$ and pour it into a beaker containing $400 \mathrm{~mL}$ of $4 \mathrm{M} \mathrm{HCl}$ (aq). A bright-orange precipitate may form immediately.

! CAUTION Handle the hot solution with care.

40 Stir the solution for $2 \mathrm{~h}$ and then filter through a glass frit to get the crude product. Wash it with water several times.

PAUSE POINT Dry the crude product in air overnight.

41 Pack a chromatography column $(6.4 \mathrm{~cm}$ i.d. $\times 63.5 \mathrm{~cm}$ long with a $500-\mathrm{ml}$ reservoir) with silica gel $(15-20 \mathrm{~cm})$ using a 33:1 (v/v) mixture of $\mathrm{CHCl}_{3}$ and $\mathrm{CH}_{3} \mathrm{OH}$. Cover the top of the column with a layer of sand $(0.5 \mathrm{~cm}$ thick). 
PROTOCOL

42 Load the crude compound from Step 40 and elute the column under gravity with $33: 1$ (v/v) $\mathrm{CHCl}_{3}$ and $\mathrm{CH}_{3} \mathrm{OH}$ ( $\sim 2$ liters). Note that the column can also be eluted under air pressure.

43| Identify fractions containing 5 by eluting TLC silica gel plates with 9:1 (v/v) $\mathrm{CHCl}_{3}$ and $\mathrm{CH}_{3} \mathrm{OH}$ (retention factor $\left.\left(R_{\mathrm{f}}\right)=0.57\right)$.

44| Remove solvents from the collected fractions by rotary evaporation $\left(\sim 40^{\circ} \mathrm{C}\right)$ to provide the desired product 5 (a light orange solid).

45 Dry 5 under vacuum. Compound 5 can be recrystallized from hot $\mathrm{C}_{6} \mathrm{H}_{5} \mathrm{Cl}$.

PAUSE POINT Compound 5 can be stored safely at $4{ }^{\circ} \mathrm{C}$ for at least 3 years.

\section{Synthesis of 2-\{2-chloro-6-hydroxy-5-[(2-methyl-quinolin-8-ylamino)-methyl]-3-oxo-3H-xanthen-9-y\}-benzoic acid TIMING $\sim 2$ days \\ 46 Weigh out $30 \mathrm{mg}$ of $5(0.076 \mathrm{mmol})$ and $12 \mathrm{mg}$ of 8 -aminoquinaldine (0.076 mmol) (see ref. 12).}

47| Transfer them into a round-bottomed flask $(10 \mathrm{ml})$ containing a Teflon-coated magnetic stir bar and $2 \mathrm{ml}$ of Et0Ac (2 ml). Wrap the reaction glassware with aluminum foil.

- PAUSE POINT Stir the solution overnight at room temperature. The orange precipitate that will form in the reaction is the imine form of FL (6, 2-\{2-chloro-6-hydroxy-5-[(2-methylquinolin-8-ylimino)-methyl]-3-oxo-3H-xanthen-9-yl\}-benzoic acid).

$\triangle$ CRITICAL STEP Protect the reaction mixture from light because fluorescein derivatives are light sensitive and exposure to light may lower their fluorescence response.

48 After removal of the solvent by using a rotary evaporator $\left(\sim 40{ }^{\circ}\right)$, add $2 \mathrm{~mL}$ of $\mathrm{CH}_{3} \mathrm{OH}$ in the flask containing the residue. Cool the solution in an ice bath. Cover the reaction setup with aluminum foil.

$\triangle$ CRITICAL STEP Protect the reaction solution from light (see Step 47).

49| Add $14 \mathrm{mg}$ of $\mathrm{NaBH}_{4}(0.38 \mathrm{mmol})$ into the cooled solution from Step 48.

50| Stir the reaction mixture in the ice bath for $1 \mathrm{~h}$.

PAUSE POINT Allow the solution in the same bath to slowly warm to room temperature while stirring overnight. The solution is cloudy at the beginning of the reaction, but is clarified as the reaction progresses.

51 Remove the solvent by using a rotary evaporator $\left(\sim 40^{\circ} \mathrm{C}\right)$ to obtain the crude product and dissolve it with a small portion of $\mathrm{CH}_{3} \mathrm{OH}(0.5 \mathrm{ml})$ and $\mathrm{CH}_{2} \mathrm{Cl}_{2}(0.1 \mathrm{ml})$.

52| Load the solution on the preparative TLC plate and dry it completely in air. Note that, when the solvent is completely removed from the plate in this step, a clear band of the product appears in Step 54 below.

$\triangle$ CRITICAL STEP If any solvent remains on the plate, the good separation of the final product will fail.

$\triangle$ CRITICAL STEP Protect the TLC plate from light (see Step 47).

53 Fill a TLC developing chamber of the preparative $\mathrm{TLC}$ with $\mathrm{CH}_{2} \mathrm{Cl}_{2}(67 \mathrm{ml})$ and $\mathrm{CH}_{3} \mathrm{OH}(3 \mathrm{ml})$.

54| Place the TLC plate from Step 52 in the chamber for $\sim 2 \mathrm{~h}$ until the mixture of solvents covers $95 \%$ height of the plate. Cover the chamber with aluminum foil to protect it from light (see Step 47).

55 Dry the plate in air in the dark. Please note that repeating Steps 54 and 55 with the TLC plate from Step 52 can produce better separation of the product.

56 Scrape the silica containing the band with $R_{\mathrm{f}}=0.34$ and collect the silica into an Erlenmeyer flask with a Teflon-coated magnetic stir bar.

57| Cover the flask with aluminum foil. Add $50 \mathrm{ml}$ of $\mathrm{CH}_{3} \mathrm{OH}$ to it. Stir the mixture for $2 \mathrm{~h}$.

$\triangle$ CRITICAL STEP Protect the solution from light (see Step 47).

58| Filter the solution through a glass frit covered by a bed of Celite. Collect the filtrate into a $250 \mathrm{ml}$ round-bottomed flask.

$\triangle$ CRITICAL STEP Protect the filtrate from light (see Step 47). 
59| Remove the solvent by rotary evaporation $\left(\sim 40^{\circ} \mathrm{C}\right)$ to obtain a magenta solid.

PAUSE POINT FL wrapped with aluminum foil (see Step 47) can be stored at $<-20{ }^{\circ} \mathrm{C}$ for at least 1 year.

\section{Preparation of CuFL $\odot$ TIMING $\sim 30$ min}

60| Prepare a $1 \mathrm{mM}$ solution of $\mathrm{FL}$ in DMSO at room temperature in a $15 \mathrm{ml}$ Corning centrifuge tube covered in aluminum foil. Aliquot the stock solution into Eppendorf tubes (0.1 $\mathrm{ml}$ per tube) (see ref. 12).

PAUSE POINT Tubes can be safely stored at $<-80{ }^{\circ} \mathrm{C}$ for 3 months.

$\triangle$ CRITICAL STEP Use DMSO with high purity ( $\geq 99.9 \%$; Aldrich, 276855). Protect the FL solution from light (see Step 47).

61 Combine solutions of $\mathrm{FL}\left(20 \mu \mathrm{l}\right.$ of the $1 \mathrm{mM}$ stock solution, DMSO) and $\mathrm{CuCl}_{2}\left(20 \mu \mathrm{l}\right.$ of the $1 \mathrm{mM}$ stock solution, $\left.\mathrm{H}_{2} 0\right)$ in the ratio of 1:1 to make a $0.5 \mathrm{mM}$ stock solution of CuFL at room temperature. Make sure that the Eppendorf tube in which the solutions are pooled together is carefully covered in aluminum foil.

$\triangle$ CRITICAL STEP Protect the CuFL solution from light (see Step 47). Keep the CuFL solution at room temperature. Freshly prepare the CuFL solution before use for imaging experiments.

\section{NO imaging by CuFL in human neuroblastoma SK-N-SH cells $\bigcirc$ TIMING $\sim 1$ day}

62| Plate human neuroblastoma SK-N-SH cells on six-well tissue culture plates or imaging dishes. Transfer them into an incubator $\left(37^{\circ} \mathrm{C}\right.$, a humidified atmosphere of $\left.5-10 \% \mathrm{CO}_{2}\right)$ (see ref. 12).

PAUSE POINT Incubate cells for $24 \mathrm{~h}$ after plating.

63 After $24 \mathrm{~h}$, make sure that cells have $40-50 \%$ confluency before imaging. Take plates or dishes from the incubator and remove the media by vacuum suction. Add fresh media $(1,994$ or 1,996 $\mu \mathrm{l}$ for Step 64$)$ to the plates or dishes. Incubate the plates and dishes for at least $1 \mathrm{~h}$.

$\triangle$ CRITICAL STEP Incubate the media in the incubator for at least 30 min before use, to allow equilibration of temperature and $\mathrm{CO}_{2}$ level. Remove the old media carefully to avoid detaching cells from the dish.

64| Add $4 \mu$ l of CuFL (0.5 mM, Step 61) and $2 \mu$ of $17 \beta$-estradiol (0.1 mM, REAGENT SETUP) into the media (1,994 $\mu \mathrm{l})$ of dishes or plates from Step 63. Incubate the resulting mixture to allow cells to incorporate CuFL ( $1 \mu \mathrm{M}$ final concentration in the media) and $17 \beta$-estradiol $(100 \mathrm{nM})$. As a negative control, add only $4 \mu \mathrm{l}$ of CuFL $(0.5 \mathrm{mM})$ into the media $(1,996 \mu \mathrm{l})$ of Step 63 and incubate it. The compound $17 \beta$-estradiol is a stimulator of constitutive NO synthase, and its solution is thus used as a positive control. Note that the present step can also be performed in the following way: prepare the media solutions $(2 \mathrm{ml}$, see CRITICAL STEP of Step 63$)$ containing CuFL $(1 \mu \mathrm{M})$ and $17 \beta$-estradiol $(100 \mathrm{nM})$ or only CuFL $(1 \mu \mathrm{M})$.

After removing the old media from the plates or dishes from Step 63, add the freshly prepared entire media solution and incubate the resulting mixture.

65 Take out cells from the incubator and rinse at least once with PBS. After rinsing, add $2 \mathrm{~mL}$ of PBS to the plates or imaging dishes.

$\triangle$ CRITICAL STEP Warm the PBS solution to $37^{\circ} \mathrm{C}$ before use and wash cells carefully (see Step 63).

66| Use bright-field illumination to get phase-contrast (Nikon microscope) or DIC (Zeiss microscope) images of cells after focusing on them. Obtain their fluorescence images. Take images of cells at three different positions of the plate or the dish. $\triangle$ CRITICAL STEP Image cells immediately after rinsing them with PBS. Choose healthy cells based on their morphology (www.atcc.org) for imaging. The unhealthy cells are shrunken with round shapes.

TIMING

FL: Steps 1-8, $\sim 1$ day; Steps 9-17, $\sim 4$ h; Steps 18-21, 3.5 h; Steps 22-26, $\sim 3$ days (or $\sim 1$ week); Steps 27-35, $\sim 2$ days and $2 \mathrm{~h}$ (or $>4$ days); Steps 36-45, $\sim 10$ h; Steps 46-47, $\sim 1$ day; Steps 48-59, $\sim 1$ day

CuFL: Steps 60-61, $30 \mathrm{~min}$

Imaging: Step 62, $\sim 1$ day; Steps 63-66, $\sim 2$ h

\section{? TROUBLESHOOTING}

Troubleshooting advice can be found in Table 1. 
PROTOCOL

TABLE 1 | Troubleshooting table.

\begin{tabular}{ll}
\hline Problem & Possible reasons \\
$\begin{array}{l}\text { Synthesis } \\
\text { Low yield of } \mathbf{2}\end{array}$ & Reagents (old or poor purity) \\
$\begin{array}{l}\text { Low yield and poor } \\
\text { purity of } \mathbf{3}\end{array}$ & $\begin{array}{l}\text { Poor quality of reagent (water), improper } \\
\text { work-up }\end{array}$ \\
Low yield of $\mathbf{4}$ & $\begin{array}{l}\text { Temperature change, short reaction time, } \\
\text { reagent (VAZO 88) decomposition }\end{array}$
\end{tabular}

Solution

Low yield of $\mathbf{5} \quad$ Poor quality of reagents (water)

Low yield and poor purity Poor quality of reagents (water), improper of FL performance of the preparative TLC

Use fresh 2-methylresorcinol ( $\geq 98 \%$ purity) and $\mathrm{ZnCl}_{2}$

Use pyridine treated over $3 \AA$ molecular sieves before use. Change water frequently over 7 days (Step 23)

Adjust temperature to $60{ }^{\circ} \mathrm{C}$ (Step 29, do not heat the solution above $60^{\circ} \mathrm{C}$ ). Allow the mixture to react for longer than 2 days (4-6 days) and add VAZO 88 every day in Step 29

Dry compound 4 completely under vacuum overnight before use and repeat the reaction using newly purchased anhydrous DMSO (or distilled DMSO over $\mathrm{CaH}_{2}$ )

Use fresh and anhydrous EtOAc. Dry the reagents such as $\mathbf{5}$ and 8-aminoquinaldine under vacuum overnight before use. Load small portions of the crude product carefully on the preparative TLC plate and dry it completely before running with eluents. Perform Steps 54 and 55 twice on the same TLC plate

\section{Imaging}

Photobleaching

Improper intensity of light, duration of excitation exposure, poor quality of reagents
Reduce the illumination light levels and excitation exposure time. Use solutions of FL and CuFL that are freshly prepared and are protected from light

Use cells younger than ten passages after arrival from ATCC and freshly prepared solutions of FL and CuFL. Protect the solutions of FL and CuFL from light

with low intensity upon

Old cells, poor quality of reagents

addition of $17 \beta$-estradiol

\section{ANTICIPATED RESULTS}

Analytical data

$1^{16}$. Yield, 49\%. TLC (silica, $\left.\mathrm{CH}_{3} \mathrm{OH}: \mathrm{CHCl}_{3}=3: 7\right): R_{\mathrm{f}}=0.26 ;{ }^{1} \mathrm{H} \mathrm{NMR}\left(500 \mathrm{MHz}, \mathrm{CD}_{3} \mathrm{OD}\right) \delta 6.47(\mathrm{~s}, 1 \mathrm{H}), 6.94(\mathrm{~s}, 1 \mathrm{H}), 7.38$ (dd, $J=1.2,7.2 \mathrm{~Hz}, 1 \mathrm{H}), 7.65(\mathrm{td}, J=1.5,7.5 \mathrm{~Hz}, 1 \mathrm{H}), 7.73(\mathrm{td}, J=1.5,7.2 \mathrm{~Hz}, 1 \mathrm{H}), 8.11(\mathrm{dd}, J=1.5,7.5 \mathrm{~Hz}, 1 \mathrm{H})$.

$2^{16}$. Yield, $65 \%$. TLC (silica, $\left.\mathrm{CHCl}_{3}: \mathrm{CH}_{3} \mathrm{OH}=3: 1\right): R_{\mathrm{f}}=0.77$. ${ }^{1} \mathrm{H} \mathrm{NMR}\left(300 \mathrm{MHz}, \mathrm{CD}_{3} \mathrm{OD}\right) \delta 2.32(\mathrm{~s}, 3 \mathrm{H}), 6.42$

$(\mathrm{d}, J=8.7 \mathrm{~Hz}, 1 \mathrm{H}), 6.56(\mathrm{~d}, J=9.0 \mathrm{~Hz}, 1 \mathrm{H}), 6.63(\mathrm{~s}, 1 \mathrm{H}), 6.88(\mathrm{~s}, 1 \mathrm{H}), 7.24(\mathrm{~d}, J=7.5 \mathrm{~Hz}, 1 \mathrm{H}), 7.72-7.80(\mathrm{~m}, 2 \mathrm{H}), 8.04$ $(\mathrm{d}, \mathrm{J}=7.5 \mathrm{~Hz}, 1 \mathrm{H})$.

$3^{17}$. Yield, 41\%. TLC (silica, $\left.\mathrm{CH}_{2} \mathrm{Cl}_{2}\right): R_{\mathrm{f}}=0.47 .{ }^{1} \mathrm{H} \mathrm{NMR}\left(300 \mathrm{MHz}, \mathrm{CD}_{2} \mathrm{Cl}_{2}\right) \delta 2.37(\mathrm{~s}, 3 \mathrm{H}), 6.74(\mathrm{~d}, \mathrm{~J}=8.7 \mathrm{~Hz}, 1 \mathrm{H}), 6.94$ $(\mathrm{d}, J=8.7 \mathrm{~Hz}, 1 \mathrm{H}), 7.00(\mathrm{~s}, 1 \mathrm{H}), 7.30(\mathrm{~d}, J=7.5 \mathrm{~Hz}, 1 \mathrm{H}), 7.53-7.59(\mathrm{~m}, 4 \mathrm{H}), 7.67-7.80(\mathrm{~m}, 4 \mathrm{H}), 8.06$

$(\mathrm{d}, J=7.5 \mathrm{~Hz}, 1 \mathrm{H}), 8.20-8.24(\mathrm{~m}, 4 \mathrm{H})$.

4 $^{17}$. Yield, 95\%. TLC (silica, $\left.\mathrm{CH}_{2} \mathrm{Cl}_{2}\right)$ : $R_{\mathrm{f}}=0.53 .{ }^{1} \mathrm{H}$ NMR $\left(300 \mathrm{MHz}, \mathrm{CD}_{3} \mathrm{OD}\right) \delta$ $4.80(\mathrm{~s}, 2 \mathrm{H}), 6.90(\mathrm{~d}, J=8.7 \mathrm{~Hz}, 1 \mathrm{H})$, $7.02(\mathrm{~s}, 1 \mathrm{H}), 7.08(\mathrm{~d}, J=8.7 \mathrm{~Hz}, 1 \mathrm{H})$, $7.33(\mathrm{~d}, J=7.5 \mathrm{~Hz}, 1 \mathrm{H}), 7.51(\mathrm{~s}, 1 \mathrm{H})$, 7.54-7.61 (m, 4H), 7.69-7.80 (m, 4H), $8.07(d, J=7.2 \mathrm{~Hz}, 1 \mathrm{H}), 8.22-8.27$ (m, 4H).

5 ${ }^{17}$. Yield, 22\%. TLC (silica, $\mathrm{CHCl}_{3}: \mathrm{CH}_{3} \mathrm{OH}=$ 9:1): $R_{\mathrm{f}}=0.57 .{ }^{1} \mathrm{H} \mathrm{NMR}\left(300 \mathrm{MHz}, \mathrm{CD}_{2} \mathrm{Cl}_{2}\right)$ $\delta 6.06(\mathrm{~s}, 1 \mathrm{H}), 6.65(\mathrm{~d}, J=8.7 \mathrm{~Hz}, 1 \mathrm{H})$, $6.81(\mathrm{~s}, 1 \mathrm{H}), 6.90(\mathrm{~d}, J=8.7 \mathrm{~Hz}, 1 \mathrm{H})$, $7.05(\mathrm{~s}, 1 \mathrm{H}), 7.19(\mathrm{~d}, J=7.2 \mathrm{~Hz}, 1 \mathrm{H})$, 7.67-7.70 (m, 2H), $8.03(\mathrm{~d}, J=6.9 \mathrm{~Hz}$, $1 \mathrm{H}), 10.65(\mathrm{~s}, 1 \mathrm{H}), 12.16(\mathrm{~s}, 1 \mathrm{H})$.
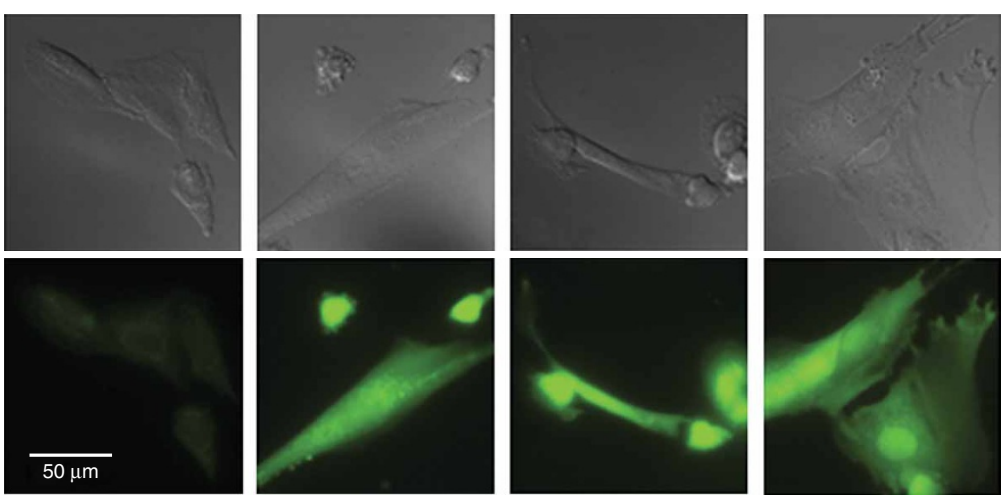

$$
\begin{array}{r}
\text { Time (min) } \\
\text { CuFL }
\end{array}
$$

$17 \beta$-Estradiol

20

$+$

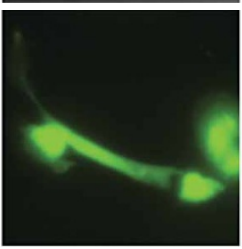

10

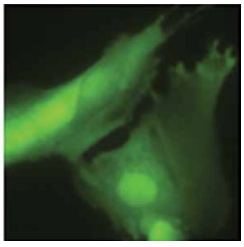

30

$+$

Figure 3 | NO detection by CuFL in SK-N-SH cells. Top, DIC images; bottom, fluorescence images. Images were taken by a Zeiss Axiovert 200M inverted epifluorescence microscope. The times depicted in the figure are the total incubation times with CuFL. 
FL $^{12}$. Yield, 22\%. TLC (silica, $\left.\mathrm{CH}_{2} \mathrm{Cl}_{2}: \mathrm{CH}_{3} \mathrm{OH}=20: 1\right): R_{\mathrm{f}}=0.34 .{ }^{1} \mathrm{H} \mathrm{NMR}\left(500 \mathrm{MHz}, \mathrm{CD}_{3} \mathrm{OD}\right): \delta 2.61(\mathrm{~s}, 3 \mathrm{H}), 4.75(\mathrm{~s}, 2 \mathrm{H})$, $6.50(\mathrm{~d}, J=9.5 \mathrm{~Hz}, 1 \mathrm{H}), 6.76(\mathrm{~s}, 1 \mathrm{H}), 6.94-7.01(\mathrm{~m}, 2 \mathrm{H}), 7.10-7.15(\mathrm{~m}, 3 \mathrm{H}), 7.20(\mathrm{~d}, J=8.5 \mathrm{~Hz}, 1 \mathrm{H}), 7.27-7.30(\mathrm{~m}, 1 \mathrm{H})$, 7.52-7.58 (m, 2H), $7.90(\mathrm{~d}, J=8.0 \mathrm{~Hz}, 1 \mathrm{H}), 8.02(\mathrm{~d}, \mathrm{~J}=7.5 \mathrm{~Hz}, 1 \mathrm{H}) ;{ }^{13} \mathrm{C}$ NMR $\left(125 \mathrm{MHz}, \mathrm{CD}_{3} 0 \mathrm{D}\right): \delta$ 181.53, 174.38, 173.44, $159.42,157.67,157.31,156.08,145.00,140.59,138.63,136.52,133.77,131.01,130.17,129.94,129.50,129.37,129.05$, $127.38,127.34,127.10,123.99,122.18,114.33,113.49,112.79,111.48,106.68,104.26,36.43,24.44 ;$ HRMS $(\mathrm{m} / \mathrm{z})$ : 535.1044 ([M-H] $]^{-}$, calculated 535.1061), $1071.2147\left([2 \mathrm{M}-\mathrm{H}]^{-}\right.$, calculated 1,071.2200).

\section{NO imaging by CuFL}

The CuFL probe showed fluorescence enhancement in the SK-N-SH cells treated with $17 \beta$-estradiol, indicating the production of NO (Fig. 3) ${ }^{12}$.

ACKNOWLEDGMENTS I gratefully acknowledge Professor Stephen J. Lippard for his support, helpful suggestions and inspiring discussions. This work was supported by a grant from the National Science Foundation (to S.J.L.). I further wish to thank the Martin Family Society at MIT for a fellowship.

COMPETING INTERESTS STATEMENT The author declares that she has no competing financial interests.

Published online at http://www.natureprotocols.com

Reprints and permissions information is available online at http://npg.nature.com/ reprintsandpermissions

1. Murad, F. Discovery of some of the biological effects of nitric oxide and its role in cell signaling. Angew. Chem. Int. Ed. 38, 1856-1868 (1999).

2. Furchgott, R.F. Endothelium-derived relaxing factor: discovery, early studies and identification as nitric oxide. Angew. Chem. Int. Ed. 38, 1870-1880 (1999).

3. Ignarro, L.J. Nitric oxide a unique endogenous signaling molecule in vascular biology. Angew. Chem. Int. Ed. 38, 1882-1892 (1999).

4. Moncada, S., Palmer, R.M.J. \& Higgs, E.A. Nitric oxide: physiology, pathophysiology, and pharmacology. Pharmacol. Rev. 43, 109-142 (1991).

5. Conner, E.M. \& Grisham, M.B. Nitric oxide: biochemistry, physiology, and pathophysiology. Methods Enzymol. 7, 3-13 (1995).

6. Tsien, R.Y. Monitoring cell calcium. in Calcium as a Cellular Regulator (eds. Carafoli, E. \& Klee, C.) 28-54 (0xford University Press, New York, 1999).

7. Burdette, S.C. \& Lippard, S.J. Meeting of the minds: metalloneurochemistry. Proc. Natl. Acad. Sci. USA 100, 3605-3610 (2003).
8. Chang, C.J. \& Lippard, S.J. Zinc metalloneurochemistry: Physiology, pathology, and probes. in Neurodegenerative Diseases and Metal Ions: Metal Ions in Life Sciences (eds. Sigel, A., Sigel, H. \& Sigel, R.K.0.) 321-370 (John Wiley \& Sons, New York, USA, 2006).

9. Soh, N. Recent advances in fluorescent probes for the detection of reactive oxygen species. Anal. Bioanal. Chem. 386, 532-543 (2006).

10. Nagano, T. \& Yoshimura, T. Bioimaging of nitric oxide. Chem. Rev. 102, 1235-1269 (2002).

11. Hilderbrand, S.A., Lim, M.H. \& Lippard, S.J. Fluorescence-based nitric oxide detection. in Topics in Fluorescence Spectroscopy (eds. Geddes, C.D. \& Lakowicz, J.R.) 163-188 (Springer, New York, USA, 2005).

12. Lim, M.H., Xu, D. \& Lippard, S.J. Visualization of nitric oxide in living cells by a copper-based fluorescent probe. Nat. Chem. Biol. 2, 375-380 (2006).

13. Lim, M.H. \& Lippard, S.J. Metal-based turn-on fluorescent probes for sensing nitric oxide. Acc. Chem. Res. 40, 41-51 (2007).

14. Gomes, A., Fernandes, E. \& Lima, J.L. Use of fluorescence probes for detection of reactive nitrogen species: a review. J. Fluorescence 16, 119-139 (2006).

15. Lim, M.H. et al. Direct nitric oxide detection in aqueous solution by copper(II) fluorescein complexes. J. Am. Chem. Soc. 128, 14364-14373 (2006).

16. Burdette, S.C., Frederickson, C.J., Bu, W. \& Lippard, S.J. ZP4, an improved neuronal $\mathrm{Zn}^{2+}$ sensor of the Zinpyr family. J. Am. Chem. Soc. $125,1778-1787$ (2003).

17. Nolan, E.M. et al. Synthesis and characterization of zinc sensors based on a monosubstituted fluorescein platform. Inorg. Chem. 43, 2624-2635 (2004). 